DOI: $10.2478 / \mathrm{v} 10014-012-0003-6$

COBISS Code 1.01

Agrovoc descriptors: triticum aestivum, soft wheat, drought resistance, acquired characters, drought stress, pregermination, seed treatment, growth control

Agris category code: F03, F60

\title{
Induction of drought tolerance with seed priming in wheat cultivars (Triticum aestivum L.)
}

\author{
Alireza EIVAZI ${ }^{1}$ \\ Received January 20, 2012; accepted February 21, 2012. \\ Delo je prispelo 20. januarja 2012, sprejeto 21. februarja 2012.
}

\begin{abstract}
Delay in sowing and low precipitation $(<300 \mathrm{~mm}$ annual $)$ in wheat (Triticum aestivum L.) farming is the major problem in the irrigated and rainfall lands of Iran. A factorial experiment for evaluating the effects of seed priming on wheat cultivars was carried out under laboratory, greenhouse and at two field conditions during seasons of 2008-2010. Arrangement of treatments were Zarrin, Shariar, Sardary and Azar cultivars as A factor, and priming treatments including distilled water (DW), osmotic solutions (10\% PEG, $2.5 \% \mathrm{KCl}, 4 \% \mathrm{MN}, 10 \%$ Urea, $5 \% \mathrm{NaCl} \mathrm{W} / \mathrm{V})$ and plant growth inducers $(20 \mathrm{ppm}$ IAA, $1000 \mathrm{ppm} \mathrm{CCC)} \mathrm{with} \mathrm{non-primed} \mathrm{seed} \mathrm{as} \mathrm{a} \mathrm{control}$ established B factor. During the second year of field experiment two separate treatments were done under drought stress and well watered conditions. Drought stress was withheld by irrigation at booting stage of plants. Maximum amount of absorbed water was determined in cultivar Shariar, $15.5 \mathrm{~g}$ DW. Seed weight of all cultivars increased the most when primed with CCC and IAA. Irrespective of the cultivar seedlings related traits revealed that treatment with CCC increased plumule and radical dry weights $(11.5$ and $8.0 \mathrm{mg})$ and their lengths $(17.2$ and $17.8 \mathrm{~cm})$. In opposite, urea pretreatment had negative effects on seedlings growth. All priming treatments increased grain yield and its components, chlorophyll content and nitrogen absorbed under field and green house conditions in four cultivars in comparison to control. Plants arising from seeds primed with potassium chloride under drought stress had the lowest percentage of variation for traits such as relative water content $(-9.3 \%)$, total dry matter $(-10.7 \%)$ and grain yield $(-4.0 \%)$ in comparison with well watered plants. Potassium chloride improved drought tolerance at all wheat cultivars. There were significant correlations between grain yield at primed with $\mathrm{KCl}$ and following wheat traits: number of spikes per square meter $(0.91 * *)$, number of grains per spike $(0.92 * *)$ and total dry matter $(0.79 *)$. Therefore, it seems that these traits could be used as indirect criteria for selection of high grain yield of cultivars for primed seed.
\end{abstract}

Key words: drought stress, hydro and osmo priming, plant growth inducers, common bread wheat

\section{IZVLEČEK}

INDUKCIJA TOLERANCE NA SUŠO S
PREDSETVENIM TRETIRANJEM SEMEN PRI
IZBRANIH SORTAH PŠENICE (Triticum aestivum L.)

Zakasnitev v setvi in majhna količina padavin $(<300 \mathrm{~mm}$ letno) sta glavna problema pri pridelavi pšenice (Triticum aestivum L.) $\mathrm{v}$ namakanih in nenamakanih območjih Irana. Izvrednotenje učinka predsetvenega tretiranja semena izbranih sort pšenice je bilo narejeno $\mathrm{s}$ faktorskim poskusom $\mathrm{v}$ laboratoriju, rastlinjaku in $\mathrm{v}$ dveh poljskih poskusih $\mathrm{v}$ sezonah 2008-2010. Poskus je bil zastavljen s štirimi sortami pšenice (Zarrin, Shariar, Sardary in Azar) kot faktorjem A in predsetvenimi tretmaji, ki so obsegali destilirano vodo (DW), raztopine osmotikov $(0 \%$ Urea, $5 \% \mathrm{NaCl} \mathrm{W} / \mathrm{V})$ in rastlinske rastne regulatorje (20 ppm IAA, $1000 \mathrm{ppm}$ CCC) primerjalno $\mathrm{z}$ netretiranimi semeni, kar je bila kontrola in faktor B. V drugem letu poljskega poskusa sta bili opravljeni še obravnavi $\mathrm{s}$ sušo in zadostnim zalivanjem. Sušni stres je bil preprečen $\mathrm{z}$ zalivanjem $\mathrm{v}$ fazi bilčenja. Največ absorbirane vode je bilo izmerjeno pri sorti Shariar, $15.5 \mathrm{~g}$ DW. Teža semen vseh sort se je povečala najbolj, kadar so bila semena pred setvijo tretirana s CCC in IAA. Ne glede na sorto se je pokazalo, da sta se suha teža mladega poganjka in korenine $(11.5 \mathrm{in} 8.0 \mathrm{mg})$ pri kalicah povečali kot tudi njuni dolžini $(17.2$ in $17.8 \mathrm{~cm})$ kadar je bilo seme pretretirano s CCC. Nasprotno je imelo predtretiranje $\mathrm{z}$ ureo negativni učinek na rast kalic. Vsa predtretiranja so povečala pridelek zrnja in njegove komponente, vsebnost klorofila in privzetje dušika $\mathrm{v}$ poskusih $\mathrm{v}$ rastlinjaku in poljskem poskusu pri vseh sortah $\mathrm{v}$ primerjavi s kontrolo. Rastline, ki so zrasle iz semen predtretiranih s $\mathrm{KCl}$ $\mathrm{v}$ razmerah sušnega stresa so imele najmanjši odstotek variabilnosti v znakih kot so reletivna vsebnost vode $(-9.3 \%)$, celokupna suha snov $(-10.7 \%)$ in pridelek zrnja $(-4.0 \%) \mathrm{v}$

1 Agricultural Research Center of West Azerbaijan Province, Urmia, Iran. P.O. Box 365, Email: alirezaeivazi@ yahoo.com 
primerjavi z dobro zalivanimi rastlinami. Natrijev klorid je pri vseh sortah pšenice izboljšal prenašanje suše. Ugotovljene so bile značilne korelacije med pridelkom zrnja pšenice, ki je bila predtretirana $\mathrm{s} \mathrm{KCl}$ in naslednjimi znaki pridelka: število klasov na kvdratni meter $\left(0.91^{* *}\right)$, število zrn na klas $(0.92 * *)$ in celokupno suho snov $\left(0.79^{*}\right)$. Zato izgleda, da bi lahko te znake uporabili kot posredni kriterij za izbor visokoproduktivnih sort pšenice, pri katerih se seme predtretira.

Ključne besede: sušni stres, vodno in osmotsko predtretiranje semen, rastlinski rastni regulatorji, krušna pšenica

\section{INTRODUCTION}

In irrigated lands, winter wheat and sugar beet fallow is the dominant rotation in 130.000 hectares of West Azerbaijan province of Iran. Planting of winter wheat is delayed after harvesting of sugar beet. In addition, low precipitation and inadequate moisture of seed zone under rainfall conditions reduces grain yield potential. Therefore, seed priming is a technology that enhances rapid (7-10 d) emergence and early establishment of wheat. Rapid and uniform field emergence is an essential prerequisite at two irrigated and rainfall conditions to reach the yield potential, quality, and ultimately profit in annual crops. Seed priming has been common pretreatment that reduces the time between seed sowing until emergence and synchronizes seedling emergence (Parera and Cantliffe 1994).

Seed priming can be accomplished through different methods such as hydro-priming (soaking in DW), osmopriming (soaking in osmotic solutions such as PEG, potassium salts, e. g., $\mathrm{KCl}, \mathrm{K}_{2} \mathrm{SO}_{4}$ ) and plant growth inducers (CCC, Ethephon, IAA) (Capron et al., 2000; Chiu et al., 2002; Harris et al., 1999; Chivasa et al., 1998).

Several investigations confirmed that seed priming has many benefits including early and rapid emergence, stand establishment, higher water use efficiency, deeper roots, increasing in root growth, uniformity in emergence, germination in wide range of temperature, break of seed dormancy, initiation of reproductive organs, better competition with weed, early flowering and maturity, resistance to environmental stresses (such as drought and salinity) and diseases (Sclerotium rolfsii L.): Higher grain yield in wheat (Triticum aestivum L.) (Ghana and Schillinger 2003), corn (Zea mays L.) (Subedi and Ma 2005) canola (Brassica napus L.) (Farhoudi and Sharifzadeh 2006), pearl millet (Pennisetum glaucum L.), chickpea (Cicer arietinum L.), rice (Oriza sativa L.) (Harris et al., 1999 and 2005) lettuce (Lactuca sativa L.) (Cantliffe et al., 1984) is reported from field and laboratory studies. Inversely, longevity of primed seed can be decreased (Bruggink et al., 1999).

Singh and Agrawal (1977) found out that wheat which seeds were treated with DW for $12 \mathrm{~h}$ increased nitrogen uptake for $11 \mathrm{~kg} / \mathrm{ha}$. Misra and Dwivedi (1980) reported that seed soaking in $2.5 \% \mathrm{KCl}$ for $12 \mathrm{~h}$ before sowing increased wheat grain yield for $15 \%$. Paul and Choudhury (1991) observed that seed soaking with 0.5 to $1 \%$ solutions with $\mathrm{KCl}$ or $\mathrm{K}_{2} \mathrm{SO}_{4}$ significantly increased plant height, grain yield and its components in wheat genotypes. Kulkarni and Eshanna (1988) stated that pre-sowing seed treatment with IAA at $10 \mathrm{ppm}$ improved root length, rate of germination, and seedling vigor.

The objective of this study was to evaluate the effect of several priming solutions on early growth, grain yield and its components under laboratory and field conditions. Specific objective was to determine the effect of seed priming on improving the response of winter wheat cultivars to drought stress under field conditions.

\section{MATERIALS AND METHODS}

Responses of four wheat cultivars, Sardary and Azar for rainfall conditions and Zarrin and Shariar for irrigated conditions, to hydro, osmo-priming and plant growth inducers were studied. Seed from latest harvest was used. and treated with eight priming media: 1- hydropriming (DW), 2osmopriming $(2.5 \% \mathrm{KCl}, 10 \%$ urea, $5 \% \mathrm{NaCl}, 4 \% \mathrm{MN}$ and $10 \%$ PEG $8000 \mathrm{~W} / \mathrm{V}$ ), 3- plant growth inducers (20 ppm IAA, and $1000 \mathrm{ppm}$ CCC). Non-treated seeds of each cultivar were used as control. All priming media were prepared in distilled water and seeds soaked at $25^{\circ} \mathrm{C}$. The duration of soaking for hydro, osmopriming and plant growth inducers were $16 \mathrm{~h}$ and $30 \mathrm{~min}$, respectively. $500 \mathrm{~g}$ of seeds of each cultivar was placed in 36 one liter capacity bashers and immersed in liquid priming media. After soaking weight of seeds was recorded and rinsed three times with tap water. All seed sets were surface sterilized with $10 \%$ sodium hypochlorite solution for 10 minutes, then rinsed with sterilized water and air dried at room temperature $\left(25^{\circ} \mathrm{C}\right)$ for 20 days. After air-drying, the weight of seed sets was recorded again, and amount of water absorbed during soaking was determined (Subedi and $\mathrm{Ma}$ 2005, Ghana and Schillinger 2003).

\subsection{Laboratory experiment}

Germination test of dried seed was measured in laboratory using a factorial experiment based on Completely Randomized Design for 36 combination treatments with five replications. Factor A and B included four wheat cultivars and nine priming media+control, respectively. For each treatment 100 seeds were placed on five $90 \mathrm{~mm}$ diameter petri dish. Two filter 
papers of Whatman No. 2 were moistened with $10 \mathrm{~mL}$ of distilled water. Seed was kept at germinator in $20^{\circ} \mathrm{C}$ for 10 days under $16 / 8 \mathrm{~h}$ day/night light. After this period plumule and radical lengths, and dry weights of them were measured.

\subsection{Greenhouse experiment}

Plants were grown in $0.5 \mathrm{~L}$ plastic pots $(5 \mathrm{~cm}$ diameter) filled with a mixture of soil, peat moss, Vermiculite and Perlite (3:1:5:1 v/v). Decision for greenhouse treatments was based on germination performance from the laboratory experiment. Urea and $\mathrm{NaCl}$ had negative effect on germination therefore these treatments were removed. The experimental design was the same as in laboratory experiment. Three uniform seed sets of each treatment were sown on 25 February 2008. At seedling emergence (10 days after planting), one gram of NH4NO3 fertilizer was applied per pot at each irrigation. Pots were regularly watered. The temperature inside the greenhouse was maintained at $25 / 15^{\circ} \mathrm{C}$ (day/night regime $\pm 3^{\circ} \mathrm{C}$ ) with $10 \mathrm{~h}$ photoperiod. At 60 days after planting, when plants were at five leaves stage, plants were removed and oven dried at $80^{\circ} \mathrm{C}$ for $24 \mathrm{~h}$ and then nitrogen uptake was measured (Bremner and Mulvaney 1982). Leaf chlorophyll content was measured with using SPAD-502.

\subsection{Field Experiments}

Table 1. General characteristics, summary of water inputs (rainfall and irrigation), class A pan evaporation and maximum and minimum temperatures in 2009-10 at field conditions.

\begin{tabular}{|c|c|c|c|c|c|c|c|}
\hline $\begin{array}{l}\text { Number of cultivars } \\
\text { Number of pretreatments }\end{array}$ & $\begin{array}{l}4 \\
7\end{array}$ & Month & $\begin{array}{c}\mathrm{Tmax} \\
\left({ }^{\circ} \mathrm{C}\right)\end{array}$ & $\begin{array}{l}\mathrm{Tmin} \\
\left({ }^{\circ} \mathrm{C}\right)\end{array}$ & $\begin{array}{l}\text { Rain } \\
(\mathrm{mm})\end{array}$ & $\begin{array}{l}\text { Irr. } \\
(\mathrm{mm})\end{array}$ & $\begin{array}{l}\text { Evap. } \\
(\mathrm{mm})\end{array}$ \\
\hline Number of combination treatments & 28 & October & 26.1 & 9.2 & 5.5 & & 124.1 \\
\hline Total plots & 280 & November & 15.6 & 9.3 & 27.7 & & 45.2 \\
\hline Density of plants & 400 & December & 8.9 & 1.5 & 32 & & \\
\hline Internals between blocks & $1.3 \mathrm{~m}$ & January & 7.7 & -0.7 & 38.4 & & \\
\hline Intervals between rows & $0.2 \mathrm{~m}$ & February & 5.9 & -3.8 & 16.6 & & \\
\hline Rows per plot & 6 & March & 14.4 & -0.4 & 44.6 & & \\
\hline Plot size & $1.2 \times 2 \mathrm{~m}^{2}$ & April & 15.9 & 5.3 & 63.6 & 25 & 57.7 \\
\hline Harvest area per plot & $1 \mathrm{~m}^{2}$ & May & 20.2 & 6.9 & 34.1 & 33 & 130.9 \\
\hline Replications per experiment & 5 & June & 28.6 & 10.7 & 3.8 & 110 & 232.3 \\
\hline Ec of water irrigation & $0.024 \mathrm{ds} / \mathrm{m}$ & July & 33 & 15.7 & 4.4 & 130 & 314.6 \\
\hline
\end{tabular}

\section{RESULTS AND DISCUSSION}

\subsection{Seed Soaking}

The greatest amount of absorbed water within cultivars was observed for Shariar with DW and the lowest amount corresponded to Zarrin and Shariar with CCC pretreatment (Table 2). Priming with $\mathrm{CCC}$ and IAA pretreatments had the shortest time of imbibition and the lowest absorbed water to the other types, but the most increased seed weight. In general, increased weight of primed seed lots was due to activation of cell respiration (Bewley and Black 1994), repairs of macromolecules
Field experiment was carried out in West Azerbaijan agricultural research center in 2009-10. The experimental field station was located in latitude $45^{\circ} 22^{\prime} \mathrm{N}, 75^{\circ} 32^{\prime} 36^{\circ} 58^{\prime}$, longitude $46^{\circ} 6^{\prime}$ and altitude $1371 \mathrm{~m}$, by a typical silty loam texture.

At the first year, seed lots used in the laboratory experiment were planted with factorial experiment based on randomized complete blocks design with five replications. Chemical fertilizers were applied pre-planting according soil analysis, therefore $100 \mathrm{~kg}$ per hectare $\mathrm{NH}_{4} \mathrm{NO}_{3}$ was applied before planting. At the booting stage, 1.5 L.ha ${ }^{-1}$ of 2- 4-D was used for weed control.

In the second year the same treatments were carried out at two separate factorial experiments based on randomized complete blocks designs under drought and well-watered conditions. In drought experiment water was withheld at the booting stage and irrigation was done after $150 \pm 5 \mathrm{~mm}$ evaporation from the Class A Pan. Well watered plots were irrigated after $75 \pm 5 \mathrm{~mm}$ evaporation from the Class A Pan (Table 1). To determine above ground biomass, four central rows were harvested upon maturity. Total dry matter, grain yield, 1000-kernel weight, spike/m2, grain per spike, relative water content (Gonzalez 1999) and plant height were measured.

Analyses of variance for all data's of laboratory, greenhouse and field experiments were conducted by Mstat-c software. Treatments were considered significantly different at $\mathrm{p} \leq 0.05$. 
Table 2. Changes in weight and moisture content of wheat seed cultivars after soaking and air-drying for 20 days in $25^{\circ} \mathrm{C}$.

\begin{tabular}{clcccccccc} 
& & \multicolumn{8}{c}{ Pretreatment } \\
\cline { 3 - 9 } Cultivar & \multicolumn{1}{c}{$\begin{array}{c}\text { Seed weight } \\
\text { (g) }\end{array}$} & \multirow{2}{*}{$\mathrm{DW}$} & $\mathrm{NaCl}$ & $\mathrm{Urea}$ & $\mathrm{KCl}$ & $\mathrm{PEG}$ & $\mathrm{MN}$ & IAA & CCC \\
& & $5 \%$ & $10 \%$ & $2.5 \%$ & $10 \%$ & $4 \%$ & $20 \mathrm{ppm}$ & $1000 \mathrm{ppm}$ \\
\hline \multirow{2}{*}{ Sardary } & water absorbed & 9.68 & 2.43 & 3.42 & 10.44 & 11.48 & 12.04 & 3.60 & 2.28 \\
& Increased seed weight & 0.42 & 0.33 & 0.32 & 0.96 & 1.12 & 1.02 & 1.20 & 1.12 \\
Azar & water absorbed & 13.32 & 2.55 & 2.96 & 9.52 & 7.76 & 12.40 & 4.4 & 3.68 \\
& Increased seed weight & 0.16 & 0.17 & 0.05 & 0.20 & 0.40 & 0.28 & 0.76 & 0.84 \\
Zarrin & water absorbed & 10.56 & 2.78 & 3.1 & 8.88 & 6.32 & 11.20 & 2.68 & 1.92 \\
& Increased seed weight & 0.52 & 0.22 & 0.25 & 0.80 & 1.16 & 0.52 & 0.96 & 1.20 \\
Shariar & water absorbed & 15.12 & 3.35 & 3.77 & 13.32 & 9.88 & 13.32 & 4.88 & 1.96 \\
& Increased seed weight & 0.4 & 0.12 & 0.15 & 0.60 & 0.88 & 0.44 & 0.96 & 1.24 \\
\hline
\end{tabular}

\subsection{Seedling Vigor and Plant Stand}

Root lengths of Shariar and Zarrin seedlings at pretreatments with IAA and CCC were 22.3, 22.0, 22.0 and $22.5 \mathrm{~cm}$, respectively (Fig. 1-A), which is much more than in other treatments. This effect could be related to CCC and IAA enhanced cell divisions at root tip (Farooq et al., 2006; Fu et al., 1988). The trend of variation between cultivars and pretreatments for plumule length was similar with root length, however, at urea pretreatment length of both decreased (Fig. 1-B). Irrespective of cultivar, pretreatments with CCC, IAA and DW with 8.1, 8.0, 8.1 $\mathrm{g}$ had bigger effect on radical dry weights (Fig. 1-C). Within pretreatments, potassium chloride had the most positive effect on plumule dry weight, $12.6 \mathrm{~g}$, and urea treatment had the most negative effect, $7.1 \mathrm{~g}$ (Fig. 1-D). Increased plumule dry weight due to osmopriming was reported by Harris et al., (2004). It caused rapid establishment of plants during germination and ultimately higher production of dry matter. Rapid germination in primed seeds was caused by increased enzyme activity, including of alfa amylase, higher levels of ATP, increased synthesis of RNA and DNA and increased number and efficiency of mitochondria (Bittencourt et al., 2005).
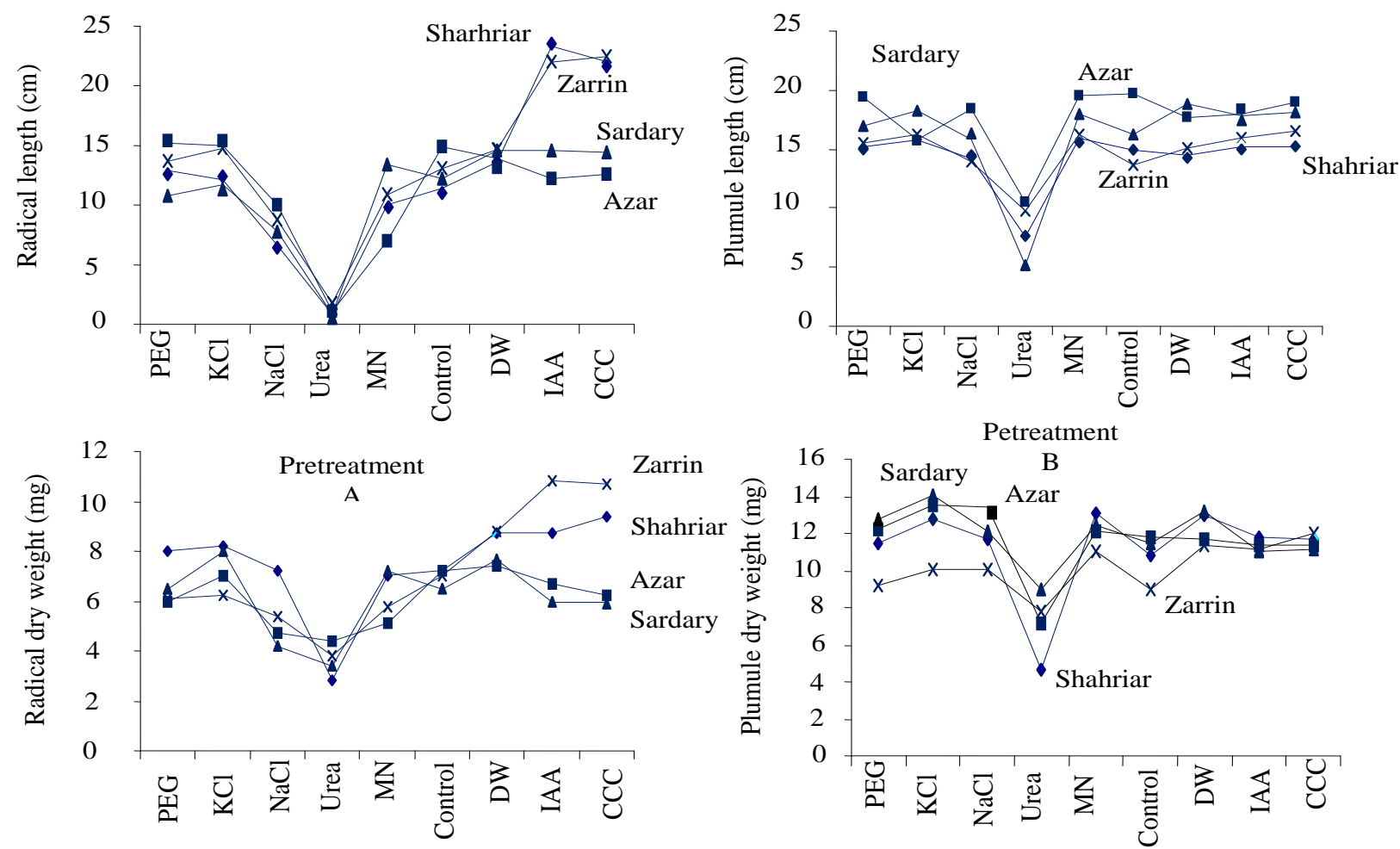

Pretreatment

$\mathrm{C}$

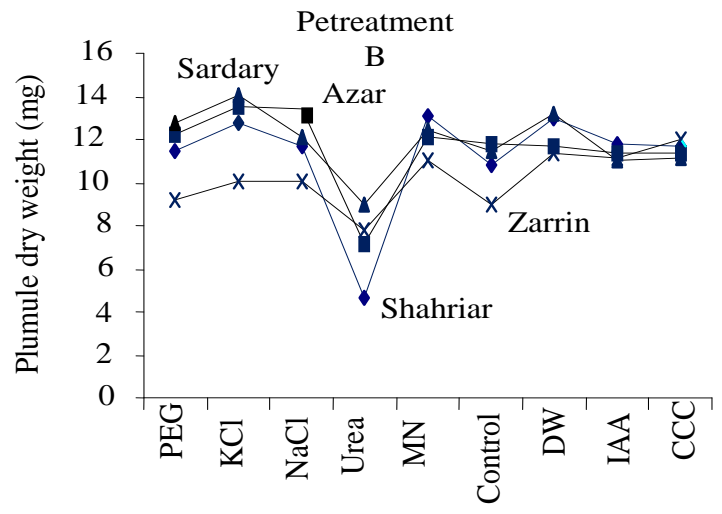

Pretreatment

$\mathrm{D}$

Figure 1. The effects of different seed pretreatments in wheat cultivars on seedling related traits. 


\subsection{Response to Nitrogen}

Cultivars Azar and Sardary had the highest chlorophyll content at IAA pretreatment while the highest content of chlorophyll in cultivars Zarrin and Sharriar was determined in DW treatment (Fig. 2-B). All pretreatments in four cultivars had higher nitrogen absorption than control. The highest nitrogen absorption, $57.3 \%$ was measured in cultivar Shariar and the lowest in cultivar Sardary, $47.6 \%$ (Fig. 2-A). In all cultivars priming with CCC and IAA resulted in higher nitrogen absorption in comparison to the other pretreatments. The reason behind that is probably the increase of the root length, which was seen in the laboratory evaluation. The increase of nitrogen absorption at priming with plant growth inducers may finally cause improvement of grain yield. Absorbed nitrogen directly effects on leaf chlorophyll content, and, in turn, improves metabolism and photosynthesis (Kulkarni and Eshanna 1988).

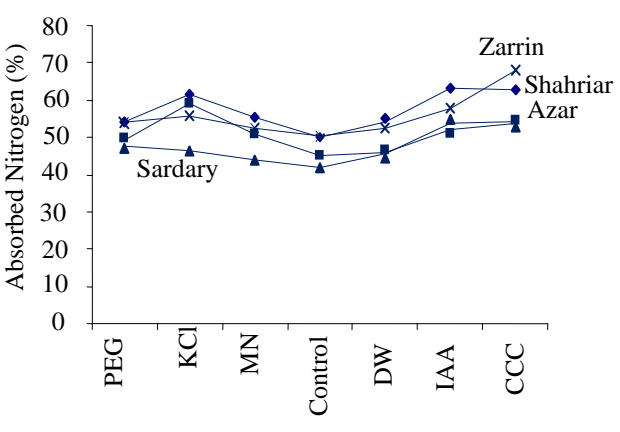

Pretreatment

A

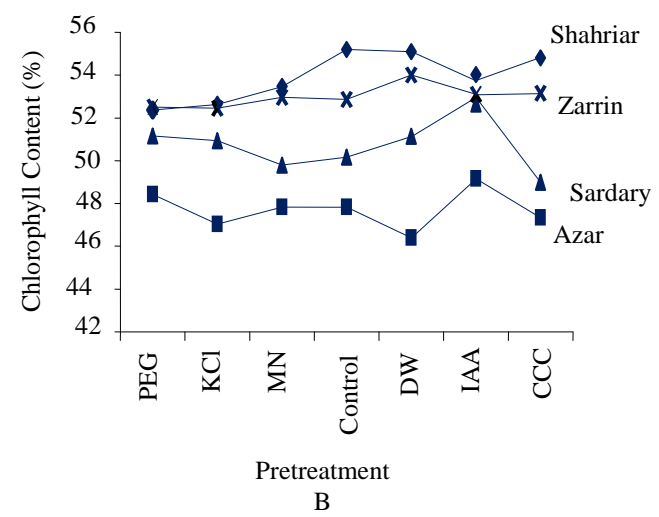

Figure. 2. The effects of different seed pretreatments in wheat cultivars on traits of chlorophyll content and absorbed nitrogen under green house conditions

\subsection{Morpho-physiological traits}

Under field conditions, all of pretreatments at four cultivars gave bigger grain yield than control and among them CCC treatment gave the highest yield, $591 \mathrm{~g} / \mathrm{m}^{2}$. Responses of cultivars varied with the type of pretreatments. Therefore, the grain yields of cultivar Shariar were 635,625 and $613 \mathrm{~g} / \mathrm{m}^{2}$ for hydropriming, $\mathrm{CCC}$ and MN, respectively. Cultivar Zarrin treated with IAA and CCC had 628 and $620 \mathrm{~g} / \mathrm{m}^{2}$ grain yield, respectively. Pretreatment with CCC gave the grain yield for cultivars Sardary and Azar 590 and $520 \mathrm{~g} / \mathrm{m}^{2}$, respectively (Fig. 3-A). The increase of grain yield with pretreatments was due to the expansion of leaves, which resulted in higher photosynthesis, assimilation and ultimately higher production of total dry matter. Accumulated priming materials in plants were effective during seed set and grain filling (Haris et al., 1999 and 2004). Many researchers reported the increase of grain yield in wheat cultivars due to pretreatments, as $37 \%$ in (Misra and Dwibedi 1980), and 15\% (Haris et al., 1999 and 2004). Success in seed priming depends on type of cultivar, osmotic potential of solution, time of priming, temperature environment, seed vigor, the rate of seed re- drying and the conditions during primed seed storage (Parera and Cantliffe 1994).

The highest number of grains per spike, 66 grains, was counted for cultivars Shariar and Zarrin, and the lowest values was determined in cultivars Azar and Sardary, with 36 and 30 grains respectively (Fig. 3-B). Irrespective of cultivar, pretreatments with IAA, CCC, DW and MN had 54, 53, 52 and 51 grains per spike, respectively. Pretreatments with CCC for 1000-Kernel weight of $45 \mathrm{~g}$ and treatments by CCC, DW and MN which gave 372, 371 and 366 spikes per square meter were the highest values of these parameters (Fig. 3-C and $\mathrm{D}$ ). The range of variations for number of spikes per square meter was between 277 and 392, related to cultivars Sardary and Zarrin, respectively.

The highets total dry matter was measured for pretreatments DW, IAA and CCC, with values of 1198 , 1185.3 and $1196.6 \mathrm{~g} / \mathrm{m}^{2}$, respectively (Fig. 3-E). The increased number of spikes per square meter at all pretreatments is a reason for higher total dry matter production. The smallest plant height was obtained for IAA and CCC pretreatments (Fig. 3-F). 

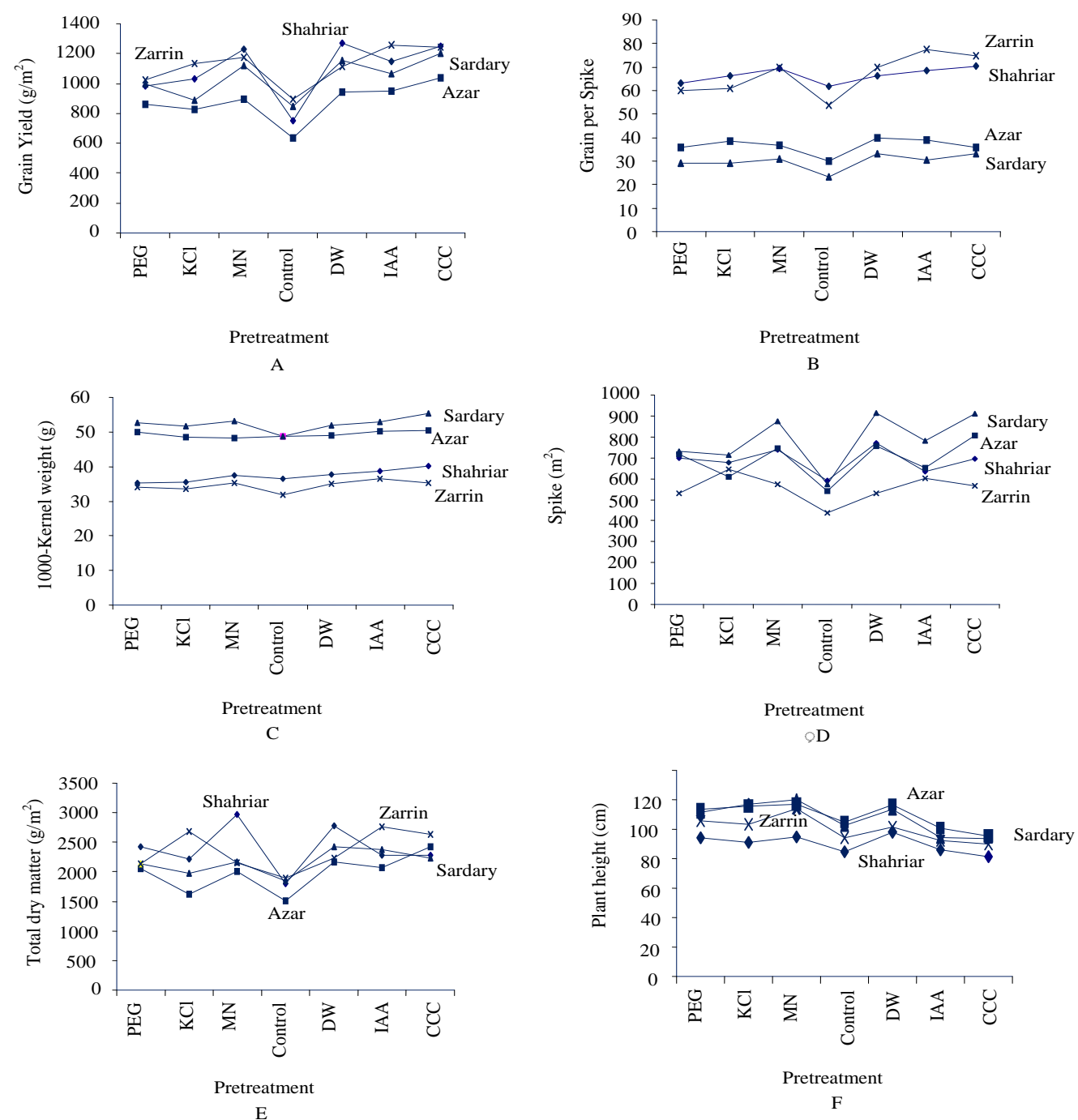

Figure. 3. The effects of different seed pretreatments in wheat cultivars on morpho-physiological traits under field conditions.

\subsection{Inducing of tolerance to drought stress}

The highest variation in grain yield under drought stress compared to well watered plants were measured in cultivar Shahriar (39\%), primed with IAA, cultivar Azar $(23 \%)$, primed with CCC, cultivar Sardary (32\%) primed with PEG and cultivar Zarrin (45\%) primed with CCC. In contrast, pretreatment with potassium chloride in all four cultivars had the lowest variations in grain yield (Table 3). Potassium ion induced tolerance to drought stress under drought treatment (Khajeh-hosseini et al., 2003). Depending on the cultivar responses of grain yield components to pretreatments were different. The percentage of variation in grain yield components within primed seeds with potassium chloride at four cultivars showed that under drought stress 1000-kernel weight had the lowest value. In contrast, except cultivar Sardary, maximum percentage variation was seen for number of spikes per square meter (Fig. 4). Saha et al., (1990) reported that performance of grain yield at primed seeds of soybean had differed and depended on cultivar type. The increase of grain yield at primed seeds in wheat, barley, rice, sorghum, chickpea and millet were stated by different researchers (Harris et al., 2001; 2004; Misra and Dwibedi 1980; Paul and Choudhury 1991). 

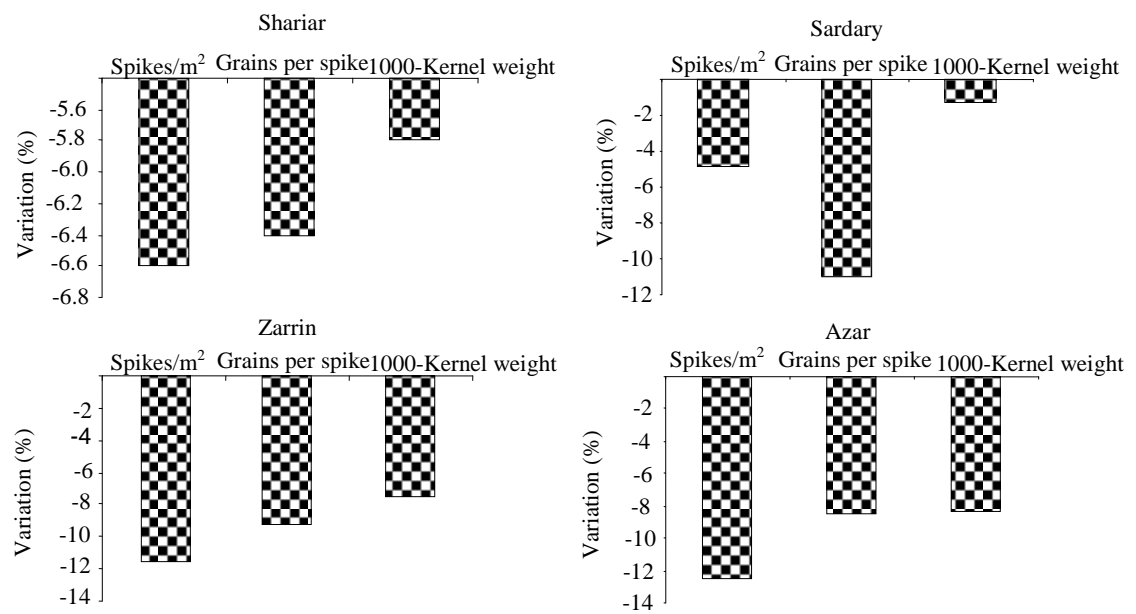

Figure. 4. Variations percentage of grain yield components of primed seed with using of potassium chloride in wheat cultivars under drought stress in comparison with well watered.

All pretreatments in our experiment had lower variation of total dry matter under drought stress compared to well-watered treatments (Table 3). Among them potassium chloride had the lowest value, which could be related to the fact that potassium induces higher tolerance to drought stress. Pretreatments resulted in high total dry matter production through effects on growth period. Primed seeds had after sowing faster germination, rapid establishment, and uniform growth.

Such a plant expands root system at shorter time compared to the control and by uptaking more water and nutrients produces photosynthetic organs rapidly and reaches earlier autotrophic stage (Duman 2006). Relative water content of wheat flag leaf primed with potassium chloride has minimal variation (Table 3 ).

Table 3. Variations percentage for traits of grain yield, total dry matter and relative water content in primed seeds of wheat cultivars under drought stress with comparison well watered.

\begin{tabular}{|c|c|c|c|c|c|c|c|}
\hline \multirow[b]{2}{*}{ Cultivar } & \multicolumn{7}{|c|}{ Grain yield $\left(\mathrm{g} / \mathrm{m}^{2}\right)$} \\
\hline & PEG $10 \%$ & $\mathrm{KCl} 2.5 \%$ & $\mathrm{MN} 4 \%$ & Control & DW & IAA 20ppm & CCC 1000ppm \\
\hline Shariar & -17.6 & -7.1 & -25.1 & -36.1 & -33.0 & -39.0 & -32.0 \\
\hline Azar & -22.5 & -1.9 & -7.4 & -15.6 & -9.1 & -16.6 & -23.9 \\
\hline Sardary & -32.4 & -2.3 & -8.8 & -27.7 & -16.5 & -16.7 & -17.1 \\
\hline \multirow[t]{2}{*}{ Zarrin } & -27.3 & -4.3 & -37.7 & -33.4 & -32.9 & -40.8 & -45.4 \\
\hline & \multicolumn{7}{|c|}{ Total dry matter $\left(\mathrm{g} / \mathrm{m}^{2}\right)$} \\
\hline Shariar & -14.2 & -12.3 & -11.0 & -18.1 & -14.3 & -15.5 & -13.3 \\
\hline Azar & -12.7 & -10.1 & -13.8 & -17.4 & -17.2 & -12.4 & -14.0 \\
\hline Sardary & -13.9 & -9.8 & -10.3 & -15.8 & -10.7 & -11.7 & -12.2 \\
\hline \multirow[t]{2}{*}{ Zarrin } & -15.7 & -10.4 & -18.1 & -20.2 & -11.0 & -13.6 & -12.3 \\
\hline & \multicolumn{7}{|c|}{ Relative water content $(\%)$} \\
\hline Shariar & -28.0 & $\begin{array}{l}-9.1 \\
\end{array}$ & -24.9 & -37.1 & -19.6 & -22.7 & -11.7 \\
\hline Azar & -25.4 & -10.5 & -17.3 & -25.6 & -14.6 & -18.9 & -12.3 \\
\hline Sardary & -19.5 & -9.6 & -16.2 & -27.1 & -11.0 & -17.9 & -13.6 \\
\hline Zarrin & -37.0 & -8.0 & -34.0 & -35.0 & -21.8 & -34.5 & -9.7 \\
\hline
\end{tabular}

\subsection{Correlation coefficients traits}

Traits of wheat such as number of spikes per square meter, number of grains per spike, total dry matter has with grain yield positive but significantly different correlation (Table 4). With increasing value of these traits, grain yield increases as well. Number of spikes per square meter and number of grains per spike at potassium chloride pretreatment had the highest percentage of variation. Therefore, these traits could be used as an indirect criterion for the selection for high grain yield. Chimenti and Hall (1994) observed positive correlation between leaf area and grain yield in sunflower under drought stress, and used it as an indirect selection in screening tolerant genotypes under drought stress. 
Table 4. Correlation coefficients of wheat cultivars traits of primed seed using of different pretreatments.

\begin{tabular}{lccccc}
\hline \multicolumn{1}{c}{ Trait } & $\begin{array}{c}\text { Grain yield } \\
\left(\mathrm{g} / \mathrm{m}^{2}\right)\end{array}$ & Spikes $/ \mathrm{m}^{2}$ & $\begin{array}{c}\text { Grains per } \\
\text { spike }\end{array}$ & $\begin{array}{c}\text { 1000-Kernel } \\
\text { weight }(\mathrm{g})\end{array}$ & $\begin{array}{c}\text { Total dry } \\
\text { matter }\left(\mathrm{g} / \mathrm{m}^{2}\right)\end{array}$ \\
\hline Spikes $/ \mathrm{m}^{2}$ & $0.91^{\star \star}$ & & & & \\
Grains per spike & $0.92^{* \star}$ & $0.83^{\star}$ & & & \\
1000-Kernel weight $(\mathrm{g})$ & 0.54 & 0.74 & 0.59 & 0.29 & 0.55 \\
Total dry matter $\left(\mathrm{g} / \mathrm{m}^{2}\right)$ & $0.79^{*}$ & $0.79^{*}$ & $0.76^{\star}$ & 0.33 & \\
Relative water content & 0.50 & 0.66 & 0.29 & \\
\hline and ${ }^{* * *}$ : Significant differences at $\mathrm{p} \leq 0.05$ and 0.01 probability levels, respectively.
\end{tabular}

\section{CONCLUSION}

Responses of wheat cultivars were different to pretreatments. Seed priming with IAA and CCC for 30 minutes had positive effects on seedling regarding nitrogen absorption and grain yield traits. It also increased the components of grain yield more than other pretreatments for 18 hours. In opposite, urea pretreatment had negative effect on seedling related traits compared to control. Therefore, we excluded urea pretreatment in green house and field experiments. The biggest percentages of variation for grain yield under drought stress compared to well-watered treatment were found for cultivars Shariar, Azar, Sardary and Zarrin with IAA $39 \%$, CCC $23 \%$, PEG $32 \%$ and CCC $45 \%$, respectively. In contrast, potassium chloride pretreatment showed at all four cultivars the minimum variations for grain yield, total dry matter and relative water content, probably due to induction of higher drought tolerance This pretreatment, except in cultivar Sardary, had the strongest effect on trait number of spikes per square meter. The trend of variations for plumule length at laboratory experiment was similar with plant height at field conditions. In the case of CCC pretreatment, the pretreatment decreased internodial lenght and subsequently plant height, but in other pretreatments it was increased. Seed priming improved grain yield up to 40 percent. Increase of $25 \%$ in absorbed nitrogen causes better vegetative growth and total dry matter compared to control. Pretreatments increased seed vigor and rapid growth at seedling stage under field conditions what had direct effect on grain yield. In addition, improving the germination percentage and uniformity emergence, pretreatment results in suitable density with increased tiller number and grains per spike. Under drought stress conditions, it is recommended that seeds be primed with potassium chloride. It is suggested that proteomic techniques should be used to identify molecular mechanisms under drought stress for primed seeds.

\section{ACKNOWLEDGEMENTS}

The financial support for this research was provided by Management and Programming Organization.

\section{REFERENCES}

Bewley, J. D., and Black, M. 1994. Seeds: Physiology of development and germination, Ed 2. Plenum Press, New York.

Bittencourt, M. C., Dias, D. C. S., Santos L. A., and Arajo, E. F. 2005. Germination of wheat. Seed Science Technology. 14: 321-325.

Bray, C. M., Davison, P. A., Ashraf, M., and Taylor, R. M. 1989. Biochemical events during osmopriming of leek seed. Annals of Applied Biology. 102: 185-193.

Bremner, J. M., and Mulvaney, R. L. 1982. Nitrogen-total, in: Methods of Soil Analysis (ed. Page, A. L.), Part 2,
Agronomy Monograph, 9, American Society of Agronomy, Madison, WI, USA, Pp. 595-622.

Bruggink, G. T., Ooms, J. J., and Van-der Toorn, P. 1999. Induction of longevity in primed seed. Seed Science Research. 9: 49-53.

Cantliffe, D. J., Fischer, J. M., and Nell, T. A. 1984. Mechanism of seed priming in circumventing thermodormancy in Lettuce. Plant Physiology. 75: 290-294.

Capron, I., Corbineua, F., Dacher, F., Job, C., Come, D., and Job, D. 2000. Sugar beet seed priming: Effects of priming conditions on germination, solubilization of 11-s globulin 
and accumulation of LEA proteins. Seed Science Research. 10: 243-254.

Chimenti, C. A., and Hall, A. J. 1994. Responses to water stress of apoplastic water fraction and bulk modulus of elasticity in sunflower (Helianthus annus L.) genotypes of contrasting capacity for osmotic adjustment. Plant and Soil. 166: 101-107.

Chiu, K. Y., Chen, C. L., and Sung, J. M. 2002. Effect of priming temperature on storability of primed sh-2 sweet corn seed. Crop Science. 42: 1996-2003.

Chivasa, W., Harris, D., Chiduza, C., and Nymudeza, P. 1998. Agronomic practices, major crops and farmer's perceptions of the importance of good stand establishment in musikavanhu. Journal of Applied Science. 4: 109-125.

Dahal, P., Bradford, K. J., and Jones, R. A. 1990. Effects of priming and endosperm integrity on seed germination rates of tomato genotypes. II. Germination at reduced water potential. Journal of Experimental Botany. 41: 1441-1453.

12- Duman, I. 2006. Effects of seed priming with PEG and $\mathrm{K}_{3}$ $\mathrm{Po}_{4}$ on germination and seedling growth in Lettuce. Pakistan Journal of Biological Sciences. 9: 923-928.

Farhoudi, R., and Sharifzadeh, F. 2006. The effects of $\mathrm{NaCl}$ priming on salt tolerance in canola (Brassica napus L.) seedlings grown under saline conditions. Indian Journal of Crop Science. 1: 74-78.

Farooq, M., Basra, S. M. A., Tabassum, R., and Ahmad, N. 2006. Evaluation of seed vigour enhancement techniques on physiological and biochemical techniques on physiological basis in coarse rice (Oriza sativa L.). Seed Science and Technology. 34: 741-750.

Gallardo, K., Claudette, J., Groot, S. P. C., Puype, M., Demol, H., Vandekerckhove, J., and Job, D. 2001. Proteomic analysis of Arabidopsis seed germination and priming. Plant Physiology. 126: 835-848.

Ghana, S. G., Schillinger, W. F. 2003. Seed priming winter wheat for germination, emergence, and yield. Crop Science. 43: 2135-2141.

Gonzalez, A., Martin, I., and Ayerbe, L. 1999. Barley yield in water stress conditions. The influence of precocity, osmotic adjustment and stomatal conductance. Field Crops Research. 62: 23-34.

Harris, D., Joshi, A., Khan, P. A., Gothakar, P., and Sodhi, P. S. 1999. On-farm seed priming in semi-arid agriculture: Development and evaluation in corn, rice and Chickpea in India using participatory method. Experimental Agriculture. 35: 15-29.

Harris, D., Raghuwanshi, B. S., Gangwar, J. S., Singh, S. C., Joshi, K. D., Rashid, A., and Hollington, P. A. 2001. Participatory evaluation by farmers of on-farm seed priming in wheat in India, Nepal, and Pakistan. Experimental Agriculture. 37: 403-415.
Harris, D., Rashid, A., Arif, M., and Yunas, M. 2004. Alleviating micronutrient deficiencies in alkaline soils of North West Frontier Province of Pakistan: on farm seed priming with zinc in wheat and chickpea. In "International Workshop on Agricultural Strategies to reduce Micronutrient Problems in Mountains and Other Marginal Areas in South and South East Asia". Kathmandu, 8-10 September, 2004. Nepal Agricultural Research Council.

Harris, D., Breese, W. A., and Kumar Rao, J. V. D. K. 2005. The improvement of crop yield in marginal environments using on farm seed priming: nodulation, nitrogen fixation, and disease resistance. Australian Journal of Agricultural Research. 56: 1211-1218.

Khajeh-Hosseini, M., Powel, A. A., and Bingham, I. J. 2003. Interaction between salinity stress and seed vigor during germination of soybean seeds. Seed Science and Technology. 27: 177-237.

Kulkarni, G. N., and Eshanna, M. R. 1988. Effect of presoaking of corn seed on seed quality. Seed Science Research. 16: 37-40.

Mazor, L., Perl, M., and Negbi, M. 1984. Changes in some ATP-dependent activities in seed during treatment with polyethylene glycol and during redrying process. Journal of Experimental Botany. 35: 1119-1127.

Misra, N. M., and Dwivedi, D. P. 1980. Effect of pre-sowing seed treatment on growth and dry matter accumulation of high yielding wheat under rain-fed conditions. Indian Journal of Agricultural Sciences. 25: 230-234.

Musa, A., Harris, D., Johansen, C., and Kumar, J. 2001. Short duration chickpea to replace fallow after man rice: the role of on farm seed priming in the High Barind Tract of Bangladesh. Experimental Agriculture. 37: 509-521.

Osborn, D. J. 1993. Function of DNA synthesis and in dormancy. Seed Science Research. 3: 43-53.

Parera, C. A., and Cantliffe, D. J. 1994. Pre-sowing seed priming. Horticultural Reviews. 16: 109-141.

Paul, S. R., and Choudhury, A. K. 1991. Effect of seed priming with potassium salts on growth and yield of wheat under rain-fed condition. Ann. Agric. Res. 12: 415-418.

Saha, R., Mandal, A. K., and Basu, R. N. 1990. Physiology of seed invigoration treatments in soybean (Glycine max L.). Seed Science and Technology. 18: 269-276.

Singh, D. K. N., and Agrawal, K. N. 1977. Effect of varieties, soil covers, forms of nitrogen and seed soaking on the uptake of major nutrients (NPK) in late sown wheat. Indian Journal of Agricultural Sciences. 22: 96-98.

Subedi, D. K., and Ma, B. L. 2005. Seed priming does not improve corn yield in a humid temperate environment. Agronomy Journal. 97: 211-218.

Vasquez-Ramos, J. M., and Sanchez, M. D. I. P. 2004. The cell cycle and seed germination. Seed Science Research. 13: $113-130$. 